\title{
WAARHEIDSTEORIEË EN INTERPRETASIE
}

\author{
Jan Botha \\ Departement Grieks \\ Potchefstroomse Universiteit vir $\mathrm{CHO}$ \\ POTCHEFSTROOM
}

\begin{abstract}
In this anticle two theories for the evaluation of the truth of incrpretations of ancicnt written texts are considered, namely, a correspondence theory of truth and a coherence theory of trith. The author opts for a coherence theory of truth. This choice is motivated by considering these two theories of truh in the context of different and conflicting interpretations of Paul's Letter to the Romans. The preference for a coherence theory of truth in the context of interpretation is also placed in a broader hermencutical and philosophical context, reflecting on such issues as foundationalism, fundamentalism, modemity and post-modemity. In the final section, a response is given to a number of issues raised by W.J. Ouweneel.
\end{abstract}

\section{INLEIDING}

In plaas daarvan om punt vir punt te reageer op W.J. Ouweneel se kritiek teen Semeion, wil ek liewer begin deur teties en meer breedvoerig die sake wat ek kernagtig en in vereenvoudigde vorm (om dit vir voorgraadse studente verstaanbaar te maak) in die boek aan die orde gestel het, uiteen te sit en te beredeneer. Die grootste gedeelte van hierdie artikel word daaraan gewy. Daarna sal ek kortliks 'n konstruksie aanbied van wat ek as die kern van Ouweneel se argument verstaan en laastens teen die agtergrond van my tetiese uiteensetting, kortliks op enkele spesifieke sake reageer.

\footnotetext{
1 Dic finansiële ondersteuning van dic Navorsingskomitee van die Fakulteit Lettere en Wysbegeerte van die PU vir CHO vir hierdie studic word hicrmee erken. Prof. Wentze! van Huyssteen (McCord Professor of Theology and Science, Princeton Theological Seminary) was so vriendelik om etlike gesprekke oor hicrdic onderwerp met my te vocr en om vrocëre wecrgawes van hicrdic artikel krities deur te werk en kommentaar daarop te lewer. Erkenning word ook verleen aan die personecllede van die Departement Bybelkunde van die Universitcil van Port Elizabeth asook dic (jespreksgrocp vir Taal- en Lelterkunde van dic PU vir CHO (onder leiding van prof. H.M. Viljoen) wat tydens verskillende geleenthede na voordragte oor hierdie onderwerp geluister het en waardevolle kritiese opmerkings gemaak het. Proff. J. Swanepoel en J.J. Venter (beide van die PU vir CHO) het ook nuttige kritiese insette gelewer gedurende die loop van die navorsing vir hicrdie artikel. Die standpunte hicrin is egter volledig my eic verantwoordelikheid en moet op geen wyse as dié van die instansies of persone hicrbo genocm, gesien word nic.
} 
In hierdie artikel sal ek onder meer die volgende standpunte beredeneer:

* As daar binne die konteks van die beoordeling van die geldigheid van wetenskaplike interpretasies van antieke geskrewe tekste gekies moet word tussen 'n korrespondensie- of 'n koherensieteorie van waarheid, geniet laasgenoemde voorkeur.

* Die keuse vir 'n koherensieteorie van waarheid is nie 'n soft option nie, nog minder is dit 'n keuse vir totale willekeur, relativisme of anargisme of impliseer dit 'n houding van anything goes. Dit wil juis die constraints in interpretasie respekteer, sy dit dan op 'n ander wyse as 'n korrespondensieteorie van waarheid.

* 'n Relasionele waarheidsmodel as filosofiese konstruksie vir besinning oor die waarheid van wetenskaplike interpretasies van 'n antieke geskrewe teks soos die Nuwe Testament ('n epistemiese saak), maak nie die bestaan van 'n werklikheid buite die kennis van die kensubjek ('n ontiese saak) van die kensubjek se instemming afhanklik nie.

* Foundationalisme en fundamentalisme is nie 'n geloofwaardige opsie binne die post-moderne intellektuele en wetenskaplike diskoers van ons tyd nie.

* Die verwerping van foundationalisme en fundamentalisme impliseer nie die aanvaarding van skeptisisme en relativisme nie.

Die wetenskap wat die interpretasie van geskrewe tekste as ondersoekveld het, is uiters interessant en baie kompleks. Of hierdie tekste nou primêr literêr-esteties (byvoorbeeld die meeste gedigte) of primêr pragmaties (byvoorbeeld 'n wet in die Staatskoerant) gerig is, of dit modern of antiek is, sekere probleme kom maar altyd weer na vore. Een van hierdie probleme is dat geskrewe tekste in mindere of meerdere mate altyd op meer as een manier geïnterpreteer kan word. Selfs tekste soos landswette wat so geskryf is dat dit so eenduidig as moontlik moet wees, het altyd een of ander skuiwergat. Daarom is daar regters wat moet uitsprake gee en advokate wat 'gapings' in die wet probeer soek om 'n saak te kan wen. Dikwels is hierdie 'gapings' gewoon plekke waar die geskrewe wet oop is vir meerdere interpretasies. In die geval van sommige literêr-estetiese tekste (wat dikwels so meerduidig as moontlik geskryf is), word die kwessie van die 'regte' interpretasie in sommige gevalle eintlik 'n irrelevante vraag. Bybelse tekste val iewers tussen-in. Binne die Christelike lesersgemeenskap 
word 'n pragmatiese dimensie in hierdie tekste beleef. Dit kanselleer egter nie die estetiese kwaliteite daarvan uit nie. Voeg daarby dat dit boonop antieke tekste is (met outeurs wat lank gelede reeds dood is, tekste wat onstaan het in sosio-kulturele kontekste wat totaal vreemd aan ons eie werklikheidsbelewing is, geskryf in vreemde, antieke, dooie tale), en dit word duidelik dat nuwe probleemkomplekse geopen word. Die bestaan van verskillende denksisteme (oor en weer bestempel as 'ortodoks' en 'ketters'), kerke en denominasies binne die Christendom - vanaf die heel vroegste tye af en dwarsdeur alle eeue - kan onder meer toegeskryf word aan die feit dat hierdie tekste op verskillende wyses geïnterpreteer word. Selfs binne Christelike tradisies wat hulleself met groot vertroue en erns as 'Skrifgetrou' bestempel, is daar dikwels meerdere en uitcenlopende interpretasies van dieselfde teksgedeeltes, byvoorbeeld rondom 'n saak soos die doop.

'n Vraag wat dus maar altyd weer na vore kom, is watter interpretasie reg? Hoe weet jy wanneer jy reg is? Watter interpretasie is waar?

Die doel van hierdie artikel is om enkele fasette van die waarheidsproblematiek in die konteks van die interpretasie van geskrewe tekste ${ }^{2}$ te ondersoek teen die agtergrond van die verskynsel van meerdere interpretasie en/of meerdere betekenisse wat aan geskrewe tekste toegeken kan word. Hierdie bespreking dien as breë oriëntering vir die tweede deel van die artikel waarin ek meer spesifiek enkele sake behandel wat deur W.J. Ouweneel as kritiek teen my voorkeur aan 'n koherensieteorie van waarheid uitgespreek is.

In die Westerse intellektuele tradisie geniet veral twee waarheidsmodelle aanhang, naamlik 'n korrespondensieteorie van waarheid en 'n koherensieteorie van waarheid. Vir die doel van hierdie bespreking word ander warheidsmodelle buite rekening gelaat.

Voordat hierdie twee waarheidsmodelle aan die orde gestel word, is dit eers nodig om enkele konkrete voorbeelde van uiteenlopende interpretasies as verwysingsraamwerk vir die verdere ontwikkeling van die argument uiteen te sit.

2 Hierdie fokus en gerigtheid is uilers belangrik. In $\$ 5.1$ word breër hieroor gehandel. 


\section{VOORBEELDE VAN UITEENLOPENDE INTERPRETASIES}

\section{1 'n Oorsprongsprobleem: die aanleiding tot die skryf van die Romeinebrief}

Uit die Romeinebrief is dit duidelik dat Paulus dit geskryf het toe hy self nog nooit in Rome was nie. Waarom het Paulus sy brief aan die Romeine geskryf? Op hierdie vraag loop die menings in die navorsingstradisie sodanig uiteen, dat die probleem al selfs 'n naam gekry het: die sogenaamde 'Romans debate' (kyk Donfried, 1977 en Wedderburn, 1989).

Kommentatore soos Nygren (1952) en Manson (1977) het die lyn van Melanchton voortgesit deur Romeine te beskou as 'n teoreties-leerstellige geskrif. So ook Bornkamm (1977) met sy karakterisering van Romeine as Paulus se 'testament'. Klein (1977) meen dat Paulus Romeine geskryf het om die apostoliese fundering daar te stel wat nog onder die Christelike gemeenskappe in Rome ontbreek het.

Volgens sommige navorsers moet die aanleiding tot die skryf van die brief in die omstandighede van die Christene in Rome gesoek word: Romeine 14 se oproepe dat die 'sterkes' die 'swakkes' in die geloof moet verdra, word gesien as ' $n$ twis tussen heidenChristene (die 'sterkes') en Joods-Christene (die 'swakkes') (so geïdentifiseer deur Minear, 1971) oor die hou van die Sabbat en die eet van offervleis al dan nie. Hierdie twis was onder andere die direkte aanleiding vir die skryf van die brief: Paulus wil graag hê daar moet harmonie onder die Christene in Rome wees, maar belangriker, dit is die rede waarom hy soveel aandag in die brief self skenk aan 'n uiteensetting van sy sienings oor die evangelie van Christus vis-à-vis die Judaïsme (vir hierdie opvatting, kyk Weifel, 1977 en Donfried, 1977a).

Ander navorsers meen dat die aanleiding tot die skryf van die brief in Paulus se persoonlike omstandighede gesoek moet word: hy is op pad Jerusalem toe om geld wat hy in Klein-Asië ingesamel het, aan die verarmde Christene daar te gaan gee (15:25). Ná sy probleme met die Galasiërs en veral die Korintiërs, is Paulus redelik omstrede en hy weet nie watter ontvangs hy in Jerusalem te wagte kan wees nie. Hy skryf dus om die ondersteuning van die Romeine te vra: hulle moet vir hom bid (15:30). Belangriker egter, hy skryf die brief omdat hy beplan om ná sy tog na Jerusalem, na Rome toe te gaan, 'n tyd lank daar te bly en die evangelie te verkondig, en dan met hulle hulp na Spanje te gaan vir verdere evangelie-verkondiging (15:24). Al hierdie persoonlike planne van Paulus het gedien as aanleiding tot die skryf van die brief (vir hierdie opvatting, kyk Jervell, 1977 en Karris, 1977). 
Wedderburn (1989) stel 'n kompromis voor en beweer dat 'n "cluster of interlocking factors" aanleiding gegee het tot die skryf van die brief:

... the presence of both Judaizing and Law-free Christians in the church there, the present situation of the church in Rome and the present situation of Paul, the visit to Jerusalem now being undertaken and the prospect of a future visit to Rome (1989:142).

Dit is duidelik dat daar binne ' $n$ histories-kritiese paradigma verskillende standpunte is oor wat tot die skryf van Romeine aanleiding kon gegee het.

Dit gaan dus hier 'n oorsprongsprobleem. Die verskillende sienings daaroor oefen groot invloed uit op hoe die brief as geheel geïnterpreteer word:

Obviously, Romans will have a very different meaning if it was conceived by Paul as an eternally valid summary of his theological position, or, if he conceived it as a response to an actual, acute problem of the first century ... (Donfried, 1977b:xvii).

\section{2 'n 'Leerstellige' probleem: die 'ek' van Romeine 7:7-25}

Die gedeelte in Romeine 7 waar die 'ek' worstel met "die goeie wat ek wil doen, doen ek nie, maar die slegte wat ek nie wil doen nie, dit doen ek. En as ek nou doen wat ek nie wil doen nie, dan is dit nie meer ek wat dit doen nie, maar die sonde wat in my woon." (7:19-20) en wat eindig met die uitroep "ek ellendige mens, wie sal my van hierdie doodsbestaan verlos?" (7:24), is welbekend as een van die klassieke voorbeelde van uiteenlopende interpretasies in die Nuwe Testament. Wie is hierdie 'ek'?

Die verskillende interpretasies van Romeine 7:7-25 deur die loop van die eeue kan soos volg saamgevat word (kyk Newman, 1983:126-133; Dunn, 1975:258-264):

1. 'n Outobiografiese interpretasie: die gedeelte beskryf Paulus se persoonlike ervaring en belewenis

Hieronder volg 'n verdere verdeling:

a Dit gaan oor Paulus se verlede, sy ervaring voordat hy 'n Christen geword het.

b Dit beskryf Paulus se gemoedstoestand nadat hy 'n Christen geword het ('n interpretasielyn wat so ver teruggaan as Augustinus - hoewel Augustinus vóor sy 
stryd met Pelagius ook interpretasie $2 b$ voorgestaan het).

2. 'n Universele interpretasie: dit is refleksie op die ervaring van alle mense:

Hierdie interpretasie het die volgende belangrike verdere verdeling:

a Die 'ek' sluit Paulus en ander mense in, met die betekenis van 'ons as Christene' (Luther se grondbeskouing dat die Christengelowige simul iustus et peccatur is, bou onder meer op hierdie interpretasie).

b Die 'ek' sluit Paulus en ander mense in, in die betekenis van 'ons as mense in ons voor-Christelike staat', ante gratiam ('n interpretasielyn wat redelik algemeen in die kerk van die eerste drie eeue voorgestaan is, later deur Pelagius, en nog later was dit onder die sestiende-eeuse Arminiane baie gewild).

'n Moderne variasie op interpretasie $2 b$ is die charismatiese opvatting van 'volmaakte heiligheid' reeds in hierdie lewe: mense wat Christene geword het en 'n second blessing ontvang het, ervaar nie meer die innerlike tweestryd wat in Romeine 7 beskryf word nie.

Onder eksegete wat binne dieselfde paradigma werk, loop die menings oor hierdie saak uiteen. In navolging van die latere Augustinus, die meeste reformatore en die Gereformeerde Belydenisskrifte, kies die meeste Lutherse en gereformeerde dogmatici vir 2a, terwyl die meerderheid moderne eksegete - ook gereformeerdes soos $\mathbf{H}$. Ridderbos - saam met die kerk van die eerste drie eeue 2b kies (Ridderbos, 1977:162).

Vir al hierdie interpretasies word goeie ondersteuning in die teks en konteks gevind.

Hierdie is dus 'n interpretasieprobleem wat die Christelike belief-system ten diepste raak en wat met 'n soort referensie te doen het - waarna verwys die 'ek'?

\section{3 'n Praxis-probleern: Romeine 13:1-7 se 'onderwerping aan die owerhede'}

In 'n toespraak voor' $n$ byeenkoms van 'n geskatte miljoen lede van die (a-politiese hoofsaaklik swart) Zion Christian Church op 7 April 1985, het die voormalige SuidAfrikaanse staatspresident, P.W. Botha (1985), sy gehoor geprys as "people who love and respect their Bishop", en wat "a sincere and healthy lifestyle" het en wat respek het vir "law, order and authority". Verder in sy toespraak, het hy gesê: 
The Bible ... has a message for the governments and governed of the world. Thus we read in Romans 13 that every person be subject to the governing authorities. There is no authority except from God. Rulers are not a terror to good conduct, but to bad conduct. Do what is good, and you will receive the approval of the ruler. He is God's servant for your good (Botha, 1985:6).

Interessant genoeg het hy die dreigement "dat die owerhede diegene wat oortree, sal straf" (Romeine 13:4) verswyg. (In die verswyging lê miskien selfs 'n erger dreigement opgesluit.) Komende van dié simbool van 'n onregverdige en onderdrukkende owerheid, uitgespreek kort voordat 'n noodtoestand die eerste keer in Suid-Afrika afgekondig is, is hierdie woorde (en verswygings!) uiters gelade. Ons het dus hier 'n modelvoorbeeld van 'n praxis-geörienteerde interpretasie van die Nuwe Testament.

Ook in 1985 het die Suid-Afrikaanse Raad van Kerke (SARK) hulle lidkerke opgeroep om op 16 Junie (Sowetodag) te bid vir die beëindiging van onregverdige en onderdrukkende regering in Suid-Afrika. 'n Hele tumult het gevolg - in die pers en ook in die geledere van die SARK. Later is 'n boek gepubliseer waarin 'n aantal ondersteuners van hierdie oproep hulle saak beredeneer het (Boesak, 1986). Een van die wêreld se bekendste anti-apartheidsaktiviste, Allan Boesak, het in hierdie boek 'n bydrae geskryf oor die vraag of Romeine 13 inderdaad 'n eis vir onvoorwaardelike blinde gehoorsaamheid aan owerhede is soos wat dit dikwels deur Christene verstaan word (Boesak, 1986). Hy wys daarop dat owerhede volgens hierdie gedeelte inderdaad deur God ingestel is, maar met die uitdruklike kwalifikasie: as "dienaars van God jou ten goede" (1986:151). As owerhede dus nie aan hulle onderdane goed doen nie (soos die apartheidsregering in Suid-Afrika), verval hulle goddelike sanksie en het onderdane nie net die reg nie, maar die plig om teen hulle in opstand te kom en te bid en te werk vir hulle ondergang. Romeine 13:1-7 is beslis nie 'n oproep tot blinde gehoorsaamheid aan owerhede ongeag wat hulle doen nie. Boesak (1986:151) konkludeer:

It is our responsibility - indecd, our duty - to resist this government. It is for this reason that we are participating in the struggle for justice, peace and liberation in South Africa. And this we do, not in spite of Romans 13, but because of Romans 13.

Beide hierdie interpretasies bied tekstuele getuienis aan ter ondersteuning van die aksies wat op grond van die teks aan hoorders/lesers voorgehou wurd. Hierdie is dus 'n geval van uiteenlopende interpretasies wat aanleiding gee tot direk botsende Christelike praxis.

Teen die agtergrond van hierdie drie voorbeelde kan ons nou vervolgens aandag gee aan verskillende waarheidsmodelle en hoe dit met interpretasie verband hou. 


\section{DIE KORRESPONDENSIETEORIE VAN WAARIIEID EN INTERPRETASIE}

Hoewel dit baic verder teruggaan, het die korrespondensieteorie van watrheid veral weens die invloed van Bertrand Russell onder moderne filosowe 'n sekere aanhang verkry (Prior, 1967:223). Russell het die teorie 'waarheid berus op 'n vorm van korrespondensie/ooreenstemming tussen opvatting en feit' gestel teenoor die opvatting 'waarheid berus op koherensie', dit is, 'hoe groter samehang ons opvattings binne 'n sisteen het, hoe meer walar is hulle'.

Die oorsprong van die woord korrespondensie on die verhouding tussen denke en werklikheid aan te dui (as synde dit waarin waarheid setel), kan volgens Prior (1967:224) gevind word in die uitspraak van die negende-eeuse Joodse Neoplatonis, Isalac Israeli: veritas est adaequatio rei et intellectus (waarheid is ooreenstemming van saak en denke). Die problematiek het egter reeds al by die antieke Grieke, veral Plato en Aristoteles, aandag gekry.

In een van Plato se geskrifte (Gaetrítos) laat hy Sokrates redeneer oor wat ware en valse opvattings van mekaar onderskei. Plato verwerp die volgende eksistensieopvalting: as ' $n$ ware opvatting gerig is op iets wat is, is ' $n$ valse opvatting gerig op iets wat nic is nie. Hy redeneer dat om iets te sien of te hoor wat nie is nie, is om glad nie te sien of te hoor nie. Dit sal beteken dat om iets te dink wat nie is nie, is om glad nie te dink nie, en daarmee het hy probleme. In die plek van die eksistensie-opvatting meen Plato dat denke in verband gebring moet word met spraak (taal) en nie direk met eksistensie nie. Om te dink is nie bloot'n gerigtheid van die denke op 'n objek nie. Indien dit die geval was, sou denke nie in volie simne uitgedruk hoef te gewees het nie blote name sou voldoende gewees het. So open Plato dus die moontlikheid dat denke wat altyd in volle sinne uitgedruk moet word - foutief kan wees, selfs al is dit wataroor gedink word werklik. Daarom moet die maatstaf vir ware denke in die ooreenstemming van denke en die ware toedrag van sake gesoek word, en nie slegs in enkele name wat direk ma objekle verwys nie (Plato, Soфiozís).

Aristoteles het die korrespondensieteorie verder ontwikkel. Indien toegegce word dat die onderskeidende kenmerk van 'n substansie of 'n individuele ding die feit is dat dit teenoorgestelde kwaliteite op verskillende tye kan hê, meen hy egter nie dat stellings en opvattings op grond daarvan as verskillende 'dinge' gesien kan word op grond van hierdie kriterium nie - aangesien stellings soms waar en soms vals mag wees. Dit is egter nie aan die stellings wat verander nie, mar die feite buite die stellings wat 
verander, waaraan die waarheid of valsheid van die stellings op opvattings gemeet word: "Want dit is op grond van die feite van die saak, op grond van hulle so wees of nie so wees nie, wat 'n stelling waar of vals genoem word" (Aristoteles, Katnyopíal).

Vir ons doeleindes is dit nie nodig om die verhaal van hierdie teorie deur die res van die geskiedenis volledig hier neer te skryf nie. Verskillende variasies en aanvullings het later onder die Stoïsyne en heelwat later, onder die Middeleeuse logici, en weer heelwat later, in die twintigste eeu by G.E. Moore, B. Russell, Ramsey en Tarski voorgekom (kyk Prior, 1967:225-231).

Hoe kan hierdie waarheidsteorie in verband gebring word met die kwessie van uiteenlopende interpretasies van geskrewe tekste?

In terme van hierdie teorie moet 'n interpretasie met iets anders, 'n vasstaande grootheid buite die teks ( = die ware toedrag van sake soos dit is, die feite), ooreenstem om waar te kan wees. In die geval van tekste word hierdie ware toedrag van sake, of feite, volgens Swanepoel (1989:22-24) dikwels in een of meer van die volgende drie sake gesoek:

* Die bedoeling van die outeur.

* Hoe die teks in sy ontstaanskonteks gefunksioneer het en die wyse waarop die destydse tydgenootlike lesers dit geresipieer het.

* Die strekking van die teks.

\subsection{Outeursbedoeling}

In die geval van outeursbedoeling word van die leser verwag om die betekenis 'uit die teks te haal' wat die outeur bewustelik daar 'ingesit' het. Die leser se interpretasie moet dus korrespondeer met dit wat die outeur bewustelik bedoel het.

In praktyk is hierdie kriterium om verskillende redes nie haalbaar nie. Dikwels gebeur dit dat 'n mens self iets skryf en jy dink dit wat jy bedoel is duidelik (en natuurlik is dit steeds iets wat 'n mens so ver moontlik nastreef), maar iemand anders lees dit en kom tot ' $n$ betekenisresultaat wat jy nié bedoel het nie. 'Dit wat daar staan' en 'dit wat ek bedoel' is dus nie altyd presies ekwivalent nie. As ek as outeur nog lewe, kan ek gevra word wat ek bedoel het - dit is nou te sê as ek nog kan onthou wat ek bedoel het! Maar as die outeur nie meer lewe nie - soos Paulus - hoe kan ons vasstel wat hy bedoel het? Het hy met Romeine 13 bedoel dat die ZCC-mense hulle aan P.W. Botha moet onder- 
werp? Waarna bedoel hy om met die 'ek' in Romeine 7 te verwys? 'n Mens sou selfs in laasgenoemde geval kon vra of Paulus self geweet het wat hy bedoel en of dit hoegenaamd 'n problematiek is waarop hy bewustelik gereflekteer het. Ons kan Paulus dit egter nie meer vra nie. Outeurbedoeling is (veral in die geval van antieke tekste) nie vasstelbaar nie (vir 'n vollediger beredenering van die nie-haalbaarheid van die kriterium van outeursbedoeling, kyk Shipley, 1966:326-329).

Tekstuele betekenis is dikwels ook méer as wat outeurs bewustelik sou kon bedoel het. Vogels (1985:88) verduidelik dit aan die hand van 'n interessante voorbeeld: op Thomas Jefferson se monument in Washington is sy lewensleuse aangebring, 'All men are created equal'. Wat het hy daarmee bedoel, as ons in gedagte hou dat hy slawe aangehou het, dat vroue-regte in die agtiende eeu in die VSA nie juis bestaan het nie en dat Rooms-Katolieke, om dit sag te stel, nou nie juis welkom was in die kolonies buite Maryland nie? Hy het waarskynlik bedoel: 'All white Protestant males are created equal'. Vandag sluit ons onder 'all men are,created equal' ook (soms?) vroue en mense van kleur in. Maar, is ongebore babas ook ingeslote in die referensiekader van die 'men' wat almal gelyk geskape is? Indien wel, hoe beïnvloed dit ' $n$ mens se standpunt oor aborsieproblematiek? Dit lyk dus asof, selfs al sou 'n mens so iets soos outeursbedoeling kon (re)konstrueer, daardie historiese stukkie betekenis heelwat kleiner in reikwydte is as wat latere geldige lesings van'n teks kan wees. Is alle latere lesings dus foutief vir so ver dit nie korrespondeer met hierdie klein stukkie historiese outeursbedoeling nie?

\subsection{Die wyse waarop oorspronklike teks gefunksoneer en geresipieer is}

Is korrespondensie tussen my interpretasie en hoe die teks in sy ontstaanskonteks gefunksioneer en geresipieer is 'n beter maatstaf vir watter interpretasie waar/korrek is? $\mathrm{Na}$ my oortuiging is dit nie. Ons stuit voor presies dieselfde probleem: hoe kan ons empiries vasstel hoe die eerste lesers die teks oorspronklik verstaan het? In die geval van die Romeinebrief het daar min tydgenootlike resepsies behoue gebly aan die hand waarvan ons ons moderne interpretasie sou kon toets. Een tydgenootlike resepsie van Paulus se briewe wat wel behoue gebly het, naamlik 'n uitspraak in die pseudepigrafiese brief 2 Petrus, is ook nie juis van veel nut nie: volgens hierdie skrywer het "ons geliefde broer Paulus met die wysheid wat aan hom gegee is aan julle geskrywe", maar hy voeg by: "Daar is dinge in sy [Paulus se] briewe wat moeilik is om te verstaan" (2 Petrus $3: 15-16)^{3}$. As tydgenootlike lesers dit al so moeilik gevind het om Paulus te

\footnotetext{
${ }^{3}$ Die ideaal wat Nida (1974) vir die Bybelvertaler stel, naamlik dat die huidige leser op die vertaling dicsclfde reaksie moet hề as wat die eerste lesers op die oorspronklike teks gehad het, is dus ook in praktyk mocilik haalbaar.
} 
verstatan, watter kans het ons vandag om hom 'korrek' te verstaan - dit wil sê, in ooreenstemming met hoe sy eerste lesers hom verstaan het?

\subsection{Dic strekking van die teks}

'n Verdere wyse waarop die korrespondensieteorie van waarheid met interpretasie in verband gebring kan word, is on te beweer dat my interpretasie korrespondeer met die strckking van die teks (die ko-teks)4. Volgens hierdie opvatting is die teks die toetssteen vir die heoordeling van die korrektheid (=die waarheid) van'n interpretasie. Hoewel voorstanders van hierdic idealal (onder andere die New Critics) redeneer dat dit meer halablatar is as die psigologiese kriterium van outeursbedoeling of die nouliks konstrueerbare kriterium van eerste lesersreaksie, los dit nie die probleem van meerdere en botsende interpretasies bevredigend op nie. In hierdie opsig is dit interessant om Ridderbos (1977) se interpretasie van Romeine 7 na te gatan. Hy doen besondere moeite om die strekking valn die teks (die ko-teks) uiters noukeurig nat te vors in sy versameling van argumente vir sy uiteindelike interpretasie. Tog kom hy by 'n ander (cn onversoenbare) interpretasie as die gereformeerde belydenisskrifte en die meeste gereformeerde dogmatici uit. Sowel P.W. Botha as Alan Boesak span tekstuele gegewens in ter ondersteuning van hulle direk teenoorstaande oproepe tot bepaalde optredes op grond van Romeine 13. Boesak gaan ook verder as net Romeine en vind in ander bricwe van Paulus ondersteming vir sy interpretasie van Romeine 13. Selfs die verskillende vorme van struktuuranalise wat in die sewentigerjare ontwikkel is en tot verbluffencle sofistikasie (en in sommige gevalle 'n esoteriese jargon wat selfs vir ingewydes moeilik begrypbalar is), verfyn is, gee nie in enige van ons voorbeelde van meerbere interpretasies 'n beslissende antwoord na die een of na die ander kant toe nic.

Na aanleiding van hierdie bespreking kan ons dus myns insiens nie tot 'n ander gevolgtrekking kom nie as dat korrespondensiekriteria nie bevredigend vir die beoordeling van die waarheid van interpretasies van antieke geskrewe tekste gebruik kan word nie.

Net 'n laaste opmerking nat aanleiding hiervan: die term Skrifgetrou kan op so 'n wyse hanteer word dat dit 'n korrespondensieteorie veronderstel: 'n 'Skrifgetroue' teoloog is

\footnotetext{
"Vir die onderskeid lussen konteks en ko-tcks, kyk Colterel \& Turner (1989:16)
} 
iemand wat as ideaal stel dat sy of haar interpretasies 'getrou' aan 'die Skrif' sal wees, dit wil sê, daarmee sal ooreenstem/korrespondeer. Behalwe vir die probleme rondom die begrip ooreenstem is ook die konsep die Skrif binne so 'n raamwerk problematies. Die konsep 'die Skrif' is altyd en noodwendig 'n konstruksie van verskillende lesersgemeenskappe. Smit (1991) beredeneer hierdie stelling breedvoerig en stel ook 'n tipologie voor van die verskillende wyses waarop lesersgemeenskappe hulle opvattings van 'die Bybel' konstrueer. Hy skryf onder andere:

Binne Gereformeerde dogmatiek, etiek en kerklike lewe is dit gebruiksgoed om te sê: 'volgens die Bybel', 'die Bybel leer', 'die Bybel sê', iets is 'in stryd met' of 'volgens' die Bybel, iets is 'Skriftuurlik' of nie. Agter al hierdie populêre maniere van praat en dink, skuil die Reformatoriese oortuiging dat die Bybel op een of ander wyse 'n eenheid vorm met 'n enkele, duidelike boodskap.

Juis hierdie Reformatoriese geloofsbeslissing is oor jare heen deur wetenskaplike omgang met die Bybel toenemend geproblematiseer en dikwels algeheel verwerp

In onlangse jare, diep bewus van die veelvoud in die Bybelse materiaal, het al hoe meer dogmatici, insluitende Gereformeerde teoloë, aangetoon dat die 'eenheid' van 'die Bybel' ' $n$ konstruk is, die resultaat van 'n greep, 'n samevattende, kreatiewe, verbeeldingryke ordening aan die kant van gelowige lesers van die Skrif ... (Smit 1991:167-168)

Hoe kan my interpretasie 'ooreenstem' of 'getrou wees' aan 'n grootheid wat so kompleks en meerduidig is? Wat sê 'die Skrif' in Romeine 7 en in Romeine 13? Watter interpretasie is getrou en watter een is ontrou? Die konsekwensie van 'n onbuigsame 'Skrifgetroue' houding is om eg sektaries te sal moet sê: 'my (en my groep se) interpretasie is reg en al die ander wat van ons verskil is verkeerd'. Rasionaliteit en die moontlikheid tot gesprek het teen so 'n houding nie juis 'n kans nie.

\section{DIE KOHERENSIETEORIE VAN WAARHEID EN INTERPRETASIE}

Volgens die koherensieteorie van waarheid is 'n uitspraak of oordeel waar of vals as dit saamhang of nie saamhang met 'n sisteem van ander uitsprake of oordele (White, 1967:130). So 'n sisteem kan byvoorbeeld bestaan uit elemente wat met logiese relasies onderling aan mekaar verbind is. Hoe meer 'n mens se aannames 'n onderlinge samehang vertoon, hoe waarder is dit. Die waarheid van 'n uitspraak is dus nie net van sy 
eie inhoud afhanklik nie, maar ook van die geheel waarbinne dit staan. Geen gebeurtenis of opvatting is heeltemal isoleerbaar nie, dit staan in samehang met ander gebeure of opvattings. Feite is self die resultaat van 'n lang koherente werksaamheid warin verskeie faktore ' $n$ rol speel. Die trefwoord is dus nie ooreenstemming tussen twee groothede nie, maar samehang tussen meerdere groothede.

Een van die insiggewendste maniere om hierdie waarheidsbeskouing te illustreer is waarskynlik die ontdekking wat in die kwantum-fisika gemaak is dat lig as 'n deeltjie (materie) of as golf (energie) waargeneem kan word, afhangende van die sisteem wat die navorser kies vir die beskrywing van die verskynsel lig (kyk Brink, 1985:10-26). Verskillende sisteme kan dus lei tot verskillende geldige beskrywings van 'dieselfde' verskynsel. 'n Implikasie van hierdie opvatting vir die interpretasie is dat 'dieselfde' teks meer as een onderling uitsluitende geldige interpretasie kan hê, afhangende van die raamwerk/sisteem waarbinne dit gelees word.

Volgens White (1967:130) is die koherensieteorie kenmerkend van die groot rasionalistiese sisteem-georiënteerde metafisici soos Leibniz, Spinoza, Hegel en Bradley se werk.

Toegepas op die interpretasie van antieke geskrewe tekste (sonder om daarmee noodwendig al die bagasie van hierdie histories-filosofiese tradisie waaruit die koherensieteorie ontwikkel het ook saam te neem), beteken dit dat 'n reeks elemente van 'n sovolledig-moontlike sisteem van faktore wat almal 'n rol by interpretasie speel, almal in onderlinge samehang moet wees ter ondersteuning van 'n bepaalde interpretasie. Sommige van die epistemiese waardes wat 'n mens se rasionaliteit vorm/daarstel in die geval van die interpretasie van geskrewe tekste, is die volgende:

* die epistemologiese en metodologiese aannames van die interpreteerder, veral rondom sake soos

- die aard en setel van betekenis in/rondom/tussen tekste ('n teksbeskouing),

- 'n samehangende taalfilosofie en 'n besef van die implikasies van die talige dimensie van kennis,

- die aard van referensie (in samehang met die taalfilosofie wat gekies word: referensie binne strukturalisme en dekonstruksie is iets totaal anders as referensie binne 'n naïef-realistiese werklikheid- en teksbeskouing), 
- die verhouding tussen taal en werklikheid,

- modelle vir die verstaan van 'die werklikheid' (ontologiese aannames),

- modelle vir die verstaan van 'die samelewing', dit wil sê, sosiologiese aannames. 'n Voorbeeld van sulke aannames is Berger \& Luckmann (1967) se teorie van reality as 'n social construction en die rol van taal as simbolesisteem in die skepping van 'n symbolic universe,

- die rol van die leser in die leesproses (lees as passiewe ontvangs van die bedocling wat bewustelik deur die outeur in die teks geënkodeer is, of, lees as kreatiewe handeling deur die leser wat neerkom op die skepping van 'n 'wêreld', of, een van die variasies daartussen ${ }^{5}$ ),

* 'n konstruksie van moontlike outeursbedoeling (vir so ver die interpreteerder se epistemologiese aannames enigsins in so 'n kriterium geïnteresseerd is)

* 'n konstruksie van moontlike eerste resepsies, (vir so ver die interpreteerder se epistemologiese aannames enigsins in so 'n kriterium geïnteresseerd is)

* 'n konstruksie van tekstuele gegewens binne 'n logiese en sinvolle samehang (vir so ver die interpreteerder se epistemologiese aannames in so 'n kriterium geînteresseerd is).

'n Mens sou seker nog meer faktore kon noem. Al hierdie faktore en opvattings en aannames moet geïntegreerd saamhang en mekaar nie onderling weerspreek of uitsluit in die evaluering van die geldigheid al dan nie van bepaalde interpretasies nie.

Let daarop dat ek hier konsekwent praat van 'n konstruksie van outeursbedoeling, ' $n$ konstruksie van eerste lesersresepsie en 'n konstruksie van tekstuele gegewens binne 'n samehang en aannames van die interpreteerder oor 'n verskeidenheid van sake. Hiermee wil ek die belangrike saak beklemtoon dat die kennis by die mens (die kensubjek) begin. ' $n$ Klip of 'n tafel kan nie ken nie. Dit beteken nié dat daar niks out there is buite subjektiewe kennis nie (kyk ook Wolsterstorff (1984:56-57). (Later in $\$ 5$ heelwat meer hieroor.)

\footnotetext{
5 Kyk Swanepocl (1986:315) se skematiese uiteensetting van die spektrum van aannames wat verskillende moderne literêre teorieë ten grondslag lê.
} 
Daar moet ook gelet word op 'n belangrike nuwe taalspel wat gespeel word: in plaas van die kategoriese reg/verkeerd-oordele oor interpretasies, word die terme geldig/minder geldig gebruik. Laasgenoemde terme veronderstel duidelik 'n koherensieopvatting.

Is hierdie koherensieteorie van waarheid nou die nuwe towersleutel wat vir ons gaan sê presies hoe Romeine 7 en Romeine 13 verstaan moet word en waarom Paulus die Romeinebricf geskryf het? Natuurlik nie. Om so 'n afleiding te maak uit die afwysing van die korrespondensicteoric ten gunste van die koherensieteorie kom neer op ' $n$ uiters gebrekkige begrip van wat 'n koherensieteorie behels en impliseer.

Net so min open 'n koherensieteorie die weg vir ongebreidelde anargisme en relativisme watarin 'n leser (volslae subjektiwisties) met 'n houding van anything goes gewoon net lekker 'speel' met die taaltekens en ainspraak maak op een of ander geldigheid vir watter interpretasie ook al. Romeine 7 is beslis nié 'n handleiding vir die rekenaarprogram Turbo Pascal 5 nic. Rasionaliteit met betrekking tot interpretasie veronderstel constraints. Om hierdie contraints uit spel is egter 'n hoogs komplekse aangeleentheid. 'n Kolverente waarleidsmodel stel dus hoë eise aan die interpreteerder. Dit is beslis nie 'n soft option nie. Dit is miskien juis in sy gekompliseerdheid en hoë eise wat dit stel, waarin kritiek teen die koherensieteorie ingebring kan word: as daar sovecl oorwegings is wat op soveel verskillende wyses 'n rol speel, is dit ooit haalhatar om bewus te wees van almal, om almal uit te spel, en belangrik, om almal in nie-onderling-uitsluitende samehang te integreer? Die groot aantal kommunikasiemodelle en interpretasiemodelle wat in die tekswetenskap gevind word, bevestig hoe gekomplisecrd die interpretasieproses is en hoeveel verskillende faktore almal 'n rol specl.

Aan die ander kant: finale 'antwoorde' is in interpretasie moeilik (nooit?) haalbaar nie. Nou sou 'n mens kon redeneer: watarom dan die korrespondensieteorie afskiet op grond datarvan dat dit kriteria gebruik wat nie haabaar is nie, terwyl die koherensieteoric se kriteria ook nie volledig haalbaar is nie? Hicrop sou ek reageer dat 'hailhaarheid' al dan nie, nie die enigste oorweging vir my voorkeur vir 'n koherensieopvalting is nie. 'n Koherensie-opvatting se oop oog vir meerdere dimensies van die interpretasicproblematick is 'n belangrike oorweging om eerder daaraan voorkeur te gee als alan die meer problematiese korrespondensieteorie. Hiermee is ook gesê dat 'n koherensieteorie allermins bo kritiek verhewe is: dit is nie volmak nie, dit is net beter as 'n korrespondensictcorie. Hierdie stelling kom ook nie neer op 'n verdediging van die koherensieteoric met behulp van die pragmatiese waarheidsteorie nie. Die koherensieteorie 'werk' nie net in praktyk beter as die korrespondensieteorie, mar dit 
kan ook teoreties en filosofies beter verantwoord word. Van hierdie twee teorieë is die koherensieteorie die beter een. 'n Leemte in beide die teorieë onder bespreking is dat albei op so 'n wyse gehanteer kan word dat slegs bepaalde waarheidsaspekte tot selfstandige waarheidskriteria verhef word. ${ }^{6}$ Hiermee is ook gesê dat die gesprek oor waarheidsteorieë steeds voortgaan. Die wetenskaplike soeke na altyd beter teorieë duur steeds voort.

Vir my is die beskeidenheid en openheid wat die koherensieteorie inhou veral aantreklik. Die voorlopigheid van alle kennis en wetenskaplike uitsprake en die genuanseerdheid van taalgebruik spreek my meer aan ('oortuig' my meer!) as die absolutisme (reg/verkeerd, korrek/nie korrek, wit/swart) wat dikwels met die korrespondensieopvatting geassosieer word?.

\section{WAARHEIDSMODELLE EN INTERPRETASIE BINNE 'N BREËR FILOSOFIESE EN HISTORIESE KONTEKS}

In die bespreking tot dusver is doelbewus en eksplisiet 'n afgrensing en fokus ingebou: dit gaan oor die problematiek rondom die interpretasie van antieke geskrewe tekste en die bruikbaarheid van die twee tradisionele waarheidsmodelle binne hierdie probleemkompleks.

$\mathrm{Na}$ aanleiding hiervan is sake soos relativisme en objektivisme reeds voorlopig aangeraak. Indien relativisme en objektivisme in verband gebring word met alle wetenskaplike kennis (en nie net die kennis rondom die interpretasieproblematiek nie), veral ook wanneer sake soos die breëre epistemiese en ontiese status van wetenskaplike uitsprake en oordele in debat gebring word, het ons duidelik met 'n nuwe stel probleme te doen wat'n ander fokus het.

\footnotetext{
${ }^{6}$ Wat hierdie saak betref, het Ouwenecl op 'n geldige probleem in Semeion gewys: die korrespondensicteorie is behandel en gekritiseer terwyl dic koherensietcorie slegs behandel is sonder enige kritick daarop. Uit die argumentasie hier behoort dit nou duideliker te wees dat ck nic meen dat die koherensieteorie bo kritick verhewe is nie.

${ }^{7}$ In hierdie opsig verskil die taalspel wat ek speel van dié van Ouweneel (alhoewcl hy moontlik nie sal hou van die Wittgensteinse terminologie dat hy 'n taal'spel' sou specl nic): hy oordecl dat Feinberg gelukkig korrek antwoord op 'n sekere probleem (1991:175), maar dat die relasionele warheidsmodel foutief is deurdat dit die subjektiewe funksionering van die subjek onder die wet van God sou misken (1991:182). Verder meen hy ook dat dit foutief (1991:178) is om 'n objektiewe, 'n subjektiewe en 'n relasionele waarheidsbegrip teenoor mekaar te stel (my kursiverings). Kyk ook p. 180 en p. 181 vir meer voorbeelde van 'korrckte' sienings van sake.
} 
Op hierdie punt is Ouweneel se artikel(1991:167-184) myns insiens ietwat van 'n misreuding van Semeion: Semeion is nie 'n "inleiding tot die Nuwe Testament" (soos hy dit lees, 1991:23) nie, maar 'n 'inleiding tot die interpretasie van die Nuwe Testament'. Hierin lê $\mathrm{og}$ 'n duidelike verskil in fokus en in die aard van die verbandhoudende filosofiese problematiek opgesluit. Om oor die waarheidsgehalte van my interpretasies van die Nuwe Testament te besin, is iets anders as om oor die ontiese status van die 'inhoud' valn die Nuwe Testament te besin. Skerp (en oorvereenvoudig) gestel: die Bybelwetenskaplike probeer wetenskaplike uitsprake oor die tekste van die Bybel malak, en die teoloog probeer wetenskaplike uitsprake oor (ons kennis van) God maak. Die fokus (en tot 'n groot mate die aard) van die problematiek waarmee die Bybelwetenskaplike en die teoloog hulle onderskeidelik besig hou, verski! van mekaar. ${ }^{8}$ Scmeion handel nie oor teologie nie. As Ouweneel (1991:182) dus skryf:

(d)il gatan om 'n kennisrclasic, wat nic (soos kennclik in dic relasionele watarhcidsmodel) in 'n soorl eksistensiale relasic verander mag word nic, watarby dic onliese (of objeklicwe) walarheid alhanklik gemalk word van dic emosics, paradigmas, "betrokkenheid" (Bolha 12 c.v.), consovourls van dic kensubjek.

kom hy maby daaraan om hierdie onderskeid self raak te sien. Tog laat hy myns insiens in sy kritiek teen Semeion nie genoeg ruimte vir die duidelik gestelde fokus van Semeion (p. xvi) nie, wat anders is as dié van 'n teologiese boek. (Dit bo en behalwe die feit dat dat sy afleidings ook ongeldig is omdat hy die indruk skep dat ek in Semeion watarheid totaal relativisties af hanklik van my emosies sou maak.)

Iliermee beweer ek nie dat dar geen verband tussen die Bybelwetenskap en die teologie is nie. Allermins. Sekere filosofiese kwessies kom noodwendig in beide gevalle ter sprake en kenmerkend van 'n holistiese postmoderne denksisteem word die traddsionele grense en isolasies tussen die verskillende wetenskaplike dissiplines in ieder gevil problematies. Dalarom ook dat ek in Semeion (die hele Afdeling A, p. 3-82) 'n sterk pleitdooi vir 'n interdissiplinêre benaldering tot die interpretasie van die Nuwe Testament lewer.

Swanepoel (1989:13-50) gee 'n baie insiggende uiteensetting van die breër intellektuele en historiese konteks walarbinne die problematiek van uiteenlopende en botsende lesings van tekste beskou kan word, veral ten opsigte van die filologiese hermeneutiek. Hy behandel onder andere waarheidsmodelle as een van die belangrike kenmerke van

\footnotetext{
'In Suid-Alrika is dic onderskcid lussen 'Bybelwelenskaplike' en 'Icoloog' nic so bekend as watt veral in die VSA dic geval is nic. Datar word dit algemeen gebruik en funksionecr alit in praktyk groolliks als andunduiders vall werskillende dissiplines.
} 
hierdie konteks. Hy bring dit verder in verband met die probleem van objektivisme, relativisme, relasionaliteit asook met verskillende verwante hermeneutiese tradisies. In Semeion (pp. 4-10) het ek ook twee strominge in die moderne wetenskapsfilosofie, naamlik die logiese positivisme teenoor die historiese skool (a la onder andere T.S. $\mathrm{Kuhn}$ ) hiermee in verband gebring. Hoe al hierdie sake onderling verwant is en in belangrike sake ook van mekaar verskil, hoef nie hier uitgepluis te word nie. Die stelling wat ek wil maak, is dat besinning oor die waarheid van ons interpretasies van antieke geskrewe tekste nie in isolasie van 'n veel groter intellektuele en historiese konteks gedoen kan word nie. Vir ons doel hier is dit nodig om sommige van hierdie en ook enkele ander konsepte kortliks te omskryf.

\title{
5.1 Objektivisme, relativisme en relasionaliteit
}

Swanepoel (1989:14) bestempel die probleem van objektivisme en relativisme as "kernprobleem van die twintigste eeu". Vir beide konsepte neem hy R.J. Bernstein se definisies oor:

\begin{abstract}
Objectivism is the basic conviction that there is or should be some permanent, ahistorical matrix or framework to which we can ultimately appeal in determining the nature of rationality, knowledge, truth, reality, goodness, or rightness (Bernstein, 1983:8).

In its strongest form, relativism is the basic conviction that when we turn to the examination of those concepts that philosophers have taken to be most fundamental - whether it is the concept of rationality, truth, reality, right, the good, or norms - we are forced to recognize that in the linal analysis all such concepts must be understood as relative to a specific conceptual scheme, theoretical framework, paradigm, form of life, society or culture (Bernstein, 1983:8).
\end{abstract}

Swanepoel (1989:20-21) toon aan dat, beskou vanuit die hoek van ontwikkelinge in die hermeneutiek, twee strominge onderskei kan word wat min of meer met hierdie twee posisies verband hou.

* Die stroming, geïdentifiseer met name soos Emilio Betti en E.D. Hirsch word oor die algemeen gekenmerk deur 'n soeke na objektiwiteit en hermeneutiek en word gesien as die teoretiese bron vir norme van validasie.

* Die stroming wat baie breedweg geïdentifiseer word met name soos M. Heidegger, H-G Gadamer, en meer resent (hoewel ook weer iets heel eiesoortigs), K-O Appel, J. Habermas, en nog weer heel eiesoortig, onder meer J. Derrida ${ }^{9}$, word

${ }^{9}$ Dit wil sê fenomenoloë (onder meer Gadamer), voorstanders van 'n hermeneutiek van suspisie (onder mecr Habermas), en voorstanders van dekonstruksie (onder meer Derrida) - alhocwel hicrdie mense nouliks onder een noemer tuisgebring kan word! 
oor die algemeen gekenmerk deur 'n bevraagtekening van die maatstawwe vir en later ook die soeke na objektiwiteit as sodanig in die interpretasieproses. Verset teen oorskatting van wetenskaplike metode is miskien oor die algemeen tiperend van die tweede stroom (Swanepoel, 1989:21; kyk Bleicher, 1980 vir breër agtergrond).

Die oorwegende tendens in die twintigste eeu is in die rigting van laasgenoemde. In plaas van om vir relativisme in ' $n$ sterk vorm te kies, het ek in Semeion gekies vir relasionaliteit en dit baie kortliks en kursories beredeneer (p. 12-15). In sy omvattende en hoogs tegniese proefskrif het Swanepoel (1989) dieselfde keuse gemaak en dit breedvoerig en oortuigend beredeneer aan die hand van uiteenlopende en botsende interpretasies van Catullus se carmina minora. Uiteraard kan al die nuanses en die gepaardgaande sofistikasie van hierdie komplekse argument nie hier weergegee word nie. Daarom volstaan ek met die algemene opmerking dat die keuse vir relasionaliteit 'n keuse is vir 'n beweging beyond objektivisme en relativisme (dit wat ook Bernstein 1983 as ideaal stel), dat dit rasioneel verantwoordbaar is, dat dit 'n koherensieteorie van waarheid veronderstel en dat dit 'n filosofiese konstruksie daarstel wat nuttig en bruikbaar is vir die konkrete interpretasie van tekste asook vir filosofiese besinning oor die interpretasie van tekste.

In plaas van relativisme (met die negatiewe konnotasies aan die begrip verbonde) verkies ek (kyk Semeion p. 13), soos ook Swanepoel doen, om liewer konsekwent van relasionaliteit te praat. Relasionaliteit is 'n opvatting wat konsepte soos 'waarheid' en verwante begrippe in relasie tot, dit wil sê, in verhouding met, 'n konseptuele skema, paradigma, vorm van lewe, samelewing of kultuur ${ }^{10}$ verstaan. Relasionaliteit reageer nie teen rasionaliteit as sodanig nie, maar teen 'n bepaalde opvatting van rasionaliteit wat sedert die Aufklärung die oorheersende opvatting daarvan geword het (Swanepoel, 1989:20). Die soeke na waarheid en wetenskaplike kennis is nie iets wat deur relasionaliste ligtelik opgeneem word nie en is allermins iets wat aan totale willekeur uitgelewer is (Swanepoel, 1989:20).

'n Relasionele waarheidsmodel as filosofiese konstruksie vir besinning oor die waarheid van wetenskaplike interpretasies van 'n antieke geskrewe teks soos die Nuwe Testament ('n epistemiese saak), maak nie die bestaan van God ('n ontiese saak) van die kensubjek se instemming afhanklik nie. Om so 'n afleiding te maak, is om 'n

${ }^{10}$ Die verband met die historiese skool in die wetenskapsfilosofie is duidelik. 
relasionele waarheidsmodel gebrekkig te verstaan.

Vir die argument tot op hierdie punt het ek nou aangesluit by Swanepoel (1989) se behandeling van 'n breër historiese en filosofiese konteks vir besinning oor waarheidsmodelle en interpretasie. Ek meen dat die problematiek ook gesien kan word teen die agtergrond van 'n breë geestesontwikkeling wat ek in die volgende twee onderafdelings ( $\$ 5.2$ en 5.3 ) baie kortliks aan die orde stel.

\subsection{Foundationalisme, non-foundationalisme en post-foundationalisme}

Verwant aan die objektivistiese denkhouding en die hermeneutiese tradisie waarin Betti en Hirsch staan, maar dan meer spesifiek binne die algemeen filosofiese diskoers, is die konsep foundationalisme. Foundationalisme is "the thesis that our beliefs can be warranted by appealing to some item of knowledge that is self-evident or beyond doubt" (Van Huyssteen, 1990:2).

Volgens Wolterstorff (1984:28) is foundationalisme die klassieke teorie vir teoretisering van die Westerse wêreld. Hy definieer dit op sy beurt soos volg:

\footnotetext{
Simply put, the goal of scientific endeavor, according to the foundationalist, is to form a body of theories from which all prejudice, bias, and unjustified conjecture have been eliminated. To attain this, we must begin with a firm foundation of certitude and build the house of theory on it by methods of whose reliability we are equally certain (Wolterstorff, 1984:28).
}

Indien daarop aanspraak gemaak word dat kennis op vaste fondamente berus, beteken dit dat daar 'n bevoorregte klas opvattings/oordele is wat intrinsiek geloofbaar is en wat daarom in staat is om as finale bepalers te dien vir kettings van justification. Volgens Van Huyssteen (1990:2) kan hierdie 'gegewenes' enige iets wees vanaf "sense data to universals, essences, experience and God's revelation". Teen die agtergrond van so 'n denkhouding maak Frankenberry (1987:6) die treffende opmerking dat die 'doctrine of the given' die 'comrade-in-arms' van alle foundationalism genoem kan word.

Foundationalisme het ontstaan en ontwikkel in die ondersoekveld van die epistemologie. Mouton \& Pauw (1988) toon aan dat foundationalisme formele ooreenkoms toon met sekere vorme van teologiese fundamentalisme (kyk ook Vorster, 1988). Veral binne sekere kringe in die beoefening van die Bybelwetenskappe word daar vanuit 'n fundamentalistiese perspektief gewerk. Sekere fundamentele en vaste waarhede is gegewenes en vorm die finale maatstaf vir alle uitsprake oor en na aanleiding van die Bybel. 
Van Iluyssteen (1990:2-3) redeneer dat denkers soos L. Wittgenstein, T. S. Kuhn en R. Rorty 'n duidelike en oortuigende nonfoundationalistiese reaksie geformuleer het op tradisioncle epistemologiese kwessies: "... instead of the picture of knowledge as an entity resting on fixed and immutable foundations, they offer a picture of human knowledge as an evolving social phenomenon within the web of belief". Ook vanuit die geledere van Christenwetenskaplikes verskaf Wolterstorff (1984:35-57) oortuigende argumente om nie net te konkludeer dat foundationalisme "on all fronts in bad shape" is nic, matr ook hoekom dit die geval is.

In die moderne en post-moderne intellektuele diskoers word die foundationalisme dus oor die algemeen verwerp op hierdie en ander gronde (kyk ook Mouton \& Marais, 1988:181-184). Van Huyssteen wil egter ook verder gaan as non-foundationalisme. Hy pleit vir 'n post-foundationalisme wat die valse dualisme van 'n gedateerde epistenologiese dilemma wat deur non-foundationalisme veronderstel word (nalamlik geloof/rede en verwant daaraan, objektivisme/relativisme), transendeer. Hy formuleer dit soos volg:

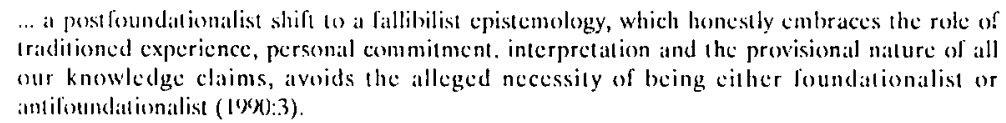

Die postmoderne holistiese epistemologie walarvoor Van Huyssteen argumenteer, kan in noue verland gesien word met die konseptuele netwerk rondom die begrip relasionalitcit soos wat dit hierbo ( $\$ 5.1)$ aangetoon is. Met 'n relasionele walaheidsmodel word dalar dus in 'n sekere sin inbeweeg binne 'n post-moderne taalspel.

Die gedagte van koherensie is ook in hierdie konteks ter sprake: in die sosiale wetenskappe, menswetenskappe, matuurwetenskappe en ook in die teologie, is daar volgens Rescher (aangehaal deur Van Huyssteen, 1990:4) veral drie kontekste van rasionaliteit: die kognitiewe konteks, die pragnatiese konteks en die evaluatiewe konteks. Binne ' $n$ holistiese epistemologie hang hierdie drie kontekste saam (is hulle koherent) "als a seamless whole" (Van Huyssteen, 199(0:5). Rasionaliteit binne die konteks van wetenskaplike werk (sy dit op die vlak van die interpretasie van geskrewe tekste of wat ook al), impliseer dat ons goeie redes moet kan gee vir wat ons $g /$, goeie redes vir hoe ons sake evalueer/beoordeel en goeie redes vir wat ons doen. 


\subsection{Modernisme en post-modernisme}

Modernisme is 'n term wat met spesifieke verwysing na 'n ontwikkeling in die VSA gedurende die negentiende eeu gebruik word. Volgens Vorster (1988:159) is modernisme 'n noemer vir die teenoorstaande 'ander' in die Amerikaanse kultuur gedurende die negentiende eeu: "Essentially it refers to the conscious adaptation of religious ideas and practices to a developing culture" (Vorster, 1988:159).

Ook in die geval van die kunste gaan dit vir die modernis ten diepste om 'n radikaal ander manier van kyk na die werklikheid (Du Plooy, 1990:77). In 'n uitstekende en goed genuanseerde artikel toon Du Plooy aan hoe omvattend die begrip modernisme is, watter geestestrominge almal op een of ander wyse daaraan verwant is en sy plaas die stroming breedweg aan die einde van die negentiende en begin van die twintigste eeu.

Die modernisme is deur sekere tradisies binne die Christendom as bedreigend en wesenlik onversoenbaar met Christelike opvattings ervaar. Byvoorbeeld: die rede waarom die Westminster Theological Seminary in Philadelphia in 1929 in die VSA ontstaan het was omdat 'n aantal dosente (onder leiding van J. Gresham Machen, Cornelius van Til en andere) daarvan oortuig was dat Princeton Theological Seminary so 'besmet' was van die modernisme, dat hulle geen ander keuse het as om weg te breek en 'n nuwe 'suiwer' teologiese inrigting tot stand te bring wat die 'ou Princeton' van die $19 \mathrm{e}$ eeu sal laat voortleef nie. Die laaste strooi vir hierdie breuk was die ondertekening van die modernistiese Auburn Affirmation deur fakulteitstede van Princeton in 1924 (Westminster Theological Seminary Catalog, 1985-1988:5-7).

In die Bybelwetenskappe het die fundamentalisme as reaksie teen die modernisme ontstaan en die Chicago Statement on Hermeneutics, waarmee Ouweneel (p.174) "op geloofsvlak" simpatiseer, is in 'n sekere sin die kulminasiepunt van die fundamentalistiese teenreaksie. Verskeie skrywers wys daarop dat daar sonder modernisme geen fundamentalisme kan wees nie. Fundamentalisme is in wese 'n reaksie teen modernisme. Daar is dus nie so iets soos pre-moderne fundamentalisme nie (kyk Lawrence, 1989:2 en Vorster, 1988). Verder is godsdienstige fundamentalisme ook nie beperk tot sekere kringe binne die Christendom nie. In sekere kringe in die Islam en in die Judaïsme kom dieselfde verskynsel voor en oefen dit groot invloed uit op die politieke gebeure (byvoorbeeld die revolusie in Iran en invloed van die godsdienspartye in die Israeli Knesset). In 'n uitstekende en omvangryke studie het Lawrence (1989) die grondtrekke van godsdienstige fundamentalisme beskryf en ook op verhelderende wyse grondige kritiek daarteen uitgespreek. 
Intussen het die filosofiese diskoers 'n nuwe fase binnegegaan, bekend onder die uiters moeilik definieerbare term post-modernisme. ${ }^{11}$ Jeanne-Francois Lyotard (aangehaal deur Comstock, 1989:196) verduidelik die term deur dit te kontrasteer met modernisme. Modernisme is volgens hom "any science that legitimizes itself with reference to a metadiscourse of this philosphical kind making an explicit appeal to some grand narrative, such as the dialectics of the Spirit, the hermeneutics of meaning, the emancipation of the rational or the working subject, or the creation of wealth". Hierdie meta-verhale wat die basis van die modernisme vorm, het verskeie variasies, byvoorbeeld in die epistemologie in die verhaal dat kennis op 'n aantal onbevraagtekenbare feite berus (Descartes), in die etiek in die verhaal dat moraliteit op 'n sekere aantal rasionele beginsels berus (Kant, Donagan) en in die wetenskap in die verhaal dat ware ontdekkings die resultaat van die toepassing van 'n enkele objektiewe metode is.

Die geldigheid van al hierdie groot (grand) legitimerende verhale word deur postmoderne denkers bevraagteken. Weens 'n "incredulity toward metanarratives" aanvaar post-moderne denkers dat daar verhale is, maar die verhale is "incommensurable", heterogeen, onbepaald, "dispersed" (Lyotard aangehaal deur Comstock, 1989:196). Comstock (1989:196) noem die volgende eksponente van post-modernisme: in godsdiensfilosofie, Mark C. Taylor, Carl Rascke en Thomas Altizer, in filosofie Richard Rorty en Jaques Derrida, in die argitektoniese idees van Michael Graves en Stanley Tigerman, in die subversiewe verhale van Donald Barthelme en John Bart, en in die ontstellende films van David Lynch.

Op alle vlakke en op alle fronte is post-moderne denkers in kritiese debat met die aannames en ideale en vastighed en sekerhede van die modernisme (kyk Comstock, 1989 en Percesepe, 1991). Rondom die konsep van waarheid skryf Comstock (1989:190) byvoorbeeld:

For prepostmodernists there was such a thing as right and wrong interpretations of the biblical text, actual historical facts to which texts did or did not correspond, and true and false propositions about the relationship between the story and reality ... Now, thanks to the work of deconstructors, philosophers of history, narrativists and critics of ideology, we are much more circumspect. Are there really any facts of the matter when it comes to interpreting texts? Even if there are, is it not clear that the rhetorical form we adopt in order to relate those facts coerces them into a message suited to our own interests? (Comstock, 1989:191.)

\footnotetext{
${ }^{11}$ Percesepe (1991:120) verkies om konsckwent liewer van "post-modern" te praat as van postmodemism omdat laasgenoemde volgens hom 'n vals dichotomic tussen modern en post-modern suggereer: "The point is, the postmodern is always already irrupting into the discourse of modernity".
} 
Of ons nou daarvan hou of nie, ons leef in 'n post-moderne era en die filosofiese diskoers van ons tyd word daardeur gedomineer. Dit is 'n denkmilieu wat nie weggewens kan word nie, en wat ongetwyfeld geldige probleme in feitlik alle moderne filosofiese aannames oopkrap. Feitlik alle 'fondamente' van alle denksisteme (in soverre die metafoor fondament nog enigsins bruikbaar is!) word krities bevraagteken, gedekonstrueer, 'uitgestel' en geproblematiseer. Uiteraard bring dit die Christen voor groot uitdagings te staan. Comstock (1989) beweer egter dat die begrip post-moderne Christen nie ' $\mathrm{n}$ contradictio in terminis is nie. Waarom dit nie is nie, word breedvoerig deur die post-moderne Christen Gary Percesepe (1991) in post-moderne taal beredeneer.

Of ek nou 'n post-moderne denkhouding in alle opsigte en met alle konsekwensies hook, line en sinker sluk, is 'n ander vraag. Ek glo nie. Ek dink ook nie ek hoéf dit te doen nie. Dit lyk juis vir my asof 'n relasionele waarheidsopvatting iets van 'n alternatief inhou - selfs 'n geloofwaardige, rasioneel verantwoordbare en dus intellektueel bevredigende alternatief. Iewers moet daar tog 'reëls' vir ons spel geld (so pleit Comstock, 1989), iewers is daar tog constraints vir interpretasie. Kyk weer: Romeine 13 is nie 'n Turbo Pascal-handleiding nie.

In hierdie artikel is daar tot op hierdie punt die volgende redenasiestrategie gevolg: enkele konkrete voorbeelde van meerdere en uiteenlopende interpretasies van konkrete Nuwe-Testamentiese tekste is verduidelik, dit is geplaas binne ' $n$ breër filosofiese agtergrond deur dit in verband te bring met die twee klassieke waarheidsmodelle, vervolgens is dit binne 'n nog breër filosofiese en historiese konteks geplaas en die argument het afgesluit met 'n kort uiteensetting van dié dominante denktradisie van die tyd waarin ons leef. Teen hierdie breë agtergrond wil ek vervolgens baie kortliks met Ouweneel in diskussie tree na aanleiding van sy kritiek op Semeion.

\section{6. 'N KONSTRUKSIE VAN DIE BASIESE KONTOERE VAN OUWENEEL SE ARGUMENT}

Ouweneel onderskei tussen teoretiese kennis (TK) en praktiese kennis (PK). Hy beskou PK as die fondament/basis en as toetssteen vir TK. Tot PK het ' $n$ mens direkte en onbemiddelde toegang deur die geloof. Geloofsuitgangspunte dien as maatstaf waaraan wetenskaplike uitsprake getoets moet word. PK is 'n mens se kennis van die werklikheid. Skematies voorgestel lyk die werklikheid vir Ouweneel soos volg: 


\section{God}

God se wet ${ }^{12}$

Kosmos

Subjek

Objek

Modaliteite

Modaliteite

Modaliteite

Modaliteite

Beide subjek en objek is ondergeskik aan God se wet, beide is deel van die kosmos en deur dit so te stel, meen Ouweneel, dat hy die subjek-objek dualisme transendeer.

\section{VRAE/OPMERKINGS/REAKSIE}

7.1 Een van die punte waarop ek en Ouweneel diagonaal van mekaar verskil, is sy konsep van 'praktiese kennis' waartoe 'n mens volgens hom direkte en onbemiddelde toegang het en die rol wat hy daaraan toeken. In sy argument funksioneer hierdie kennis as voor-teoretiese of buite-teoretiese 'gegewenhede'. Net so min as wat my keuse vir ' $n$ relasionele waarheidsmodel vir die beoordeling van die geldigheid van interpretasies hom 'oortuig' het, nog minder oortuig sy premoderne opvatting my. Trouens, sy fideïstiese foundationalisme en die postmoderne denkmilieu waarin ek my tuisvoel, is incommensurable en diskussie is uiters moeilik. Dit is 'n diskussie wat Kuhniaanse 'vertalers' benodig. As hierdie praktiese kennis 'gegee' is, as dit teorie-vry is en as hy direkte toegang daartoe het en ek nie, hoe kan ons dan daaroor praat? Moet ek nou eers oorgehaal word tot Dooyeweerd om ook hierdie 'direkte toegang' te kan hê? Kan Ouweneel konkreet uitspel wat die 'objektiewe, altyd vasstaande norme van die Goddelike wetsorde' is waarvan hy praat? (1991:183.) En belangriker, hoe ken ons dit? Die oomblik wat dit in taal uitgespel is, is dit oop en nie meer altyd vasstaande nie - gewoon omdat menslike taal altyd vir meerdere interpretasie

\footnotetext{
${ }^{12}$ In Dovycwecrdiaanse sin, nic dic Tien Gebooic nic.
} 
vatbaar is. Daarby sal ek dit behulpsaam vind as hy sy PK en TK onderskeid op die uiteenlopende interpretasies van Romeine toepas: watter interpretasie van Romeine 7 of Romeine 13 is nou PK en watter een is TK? Volgens watter kriteria kan ek dit vasstel? Watter TK is korrek - die gereformeerde belydenisskrifte se interpretasie van Romeine 7 (of is belydenisskrifte dalk PK?) of die gereformeerde eksegeet Herman Ridderbos se botsende interpretasie daarvan? Saamgevat: dat daar so iets soos 'n soort 'voor-teoretiese' kennis is (of liewer, kennis waaroor nog nie spesifiek gereflekteer is nie), hoef seker nie ontken te word nie. Hierdie soort kennis speel sekerlik ook een of ander rol in die wetenskaplike proses. Maar hierdie soort kennis kan nie tot toetssteen vir alle wetenskaplike kennis verhef word (soos Ouweneel myns insiens wil doen) nie. Dit geld natuurlik vir alle wetenskappe: die naïewe 'voor-teoretiese' kennis of empiriese belewing van die fisiese werklikheid kan sekerlik tog nie end-uit as toetssteen dien vir al die wetenskaplike werk wat die fisikus doen nie. (Watter rol speel 'teorie-vrye' kennis byvoorbeeld in die werk van die fisikus wat met gesofistikeerde teleskope die bronne van kosmiese strale waarneem en dit dan in gevordere en uiters komplekse wiskunde beskryf?) Verder problematiseer die talige aard van alle kennis (óók 'teorie-vrye' kennis) die rol wat hierdie soort kennis wel kan speel in die wetenskaplike proses. Vir die hantering van hierdie soort problematiek, bied die epistemiese waardes wat in $\$ 4$ bespreek is na my oortuiging 'n sinvolle en rasioneel-verantwoordbare sisteem vir wetenskaplike ondersoek, veral die wetenskaplike ondersoek van antieke geskrewe tekste.

7.2 Die feit dat Ouweneel sy 'praktiese kennis' 'n geloofskennis van die Skrif noem, problematiseer die saak nog veel meer as wat dit reeds as algemene epistemologiese aanname is. Wat verstaan hy onder 'die Skrif? Hoe maak hy voorsiening vir die problematiek van taal as simbolesisteem, intertekstualiteit, die rol van die leser, die verhouding tussen taal en werklikheid, ensovoorts? Wat is "die Bybelse denk- en ervaringshouding" waarvan hy praat (1991:173, my kursivering)? Wat is "onmiddellike kennis van die Skrif?" Wat is die "inhoud" van die Skrif? Dit is alles blykbaar vir Ouweneel 'gegewenhede' buite teoretiese refleksie want dit is alles dinge wat hy aanmerk as "geloofskennis" (1991:173). Kan hy dus sê wat is die 'inhoud' van die Skrif in Romeine 7? En kan hy sê wie van A. Boesak of P.W. Botha propageer 'n 'Skriftuurlike' optrede teenoor die owerhede? Selfs 'n kursoriese kennisname van die moderne Bybelwetenskap, maak dit duidelik hoe problematies 'n opvatting soos 'die inhoud' van 'die Skrif' is. Hoe word die verhouding Ou en Nuwe Testament byvoorbeeld gesien? Hoe word die verhouding tussen verskillende boeke gesien? Dit is nie gegewenhede nie, opvattings hieroor is konstruksies van die kensubjek/lesersgemeenskappe 
(Snit, 1991). Wie se konstruksie van die 'inhoud' van die Nuwe Testament is 'reg'? Cullmann, Jeremias, Bultmann, Goppelt, Ridderbos, Ladd (om maar enkeles te noem, kyk Hasel, 1978) het almal teologieë of weergawes van die 'inhoud' van die Nuwe Testament geskryf, en almal verskil van mekaar.

7.3 Dit is ' $n$ vraag of Ouweneel self die dualisme walarvan hy my beskuldig transendeer. Sy onderskeid tussen praktiese kennis en teoretiese kennis kom neer op 'n ander soort dualisme.

7.4 Sy afwysing van die fundamentalisme is te verwelkom, maar met sy keuse vir ' $n$ 'onbemiddelde praktiese kennis' verskuif hy dieselfde fundamentalistiese aannames net 'n bietjie. Deur sy onderskeid tussen teoretiese kemnis en praktiese kennis maak hy 'n deur oop om op die vlak van 'praktiese kennis' die fundamentalistiese aannames oor die Bybel onverswak te handhataf.

7.5 By Ouwencel se pleidooi vir 'n samehangende wetenskapsteorie wal in 'n samehangende kosmologie gefundeer is, vind ek aansluiting. Wanneer hy egter Dooyeweerd se filosofie as die (1991:18013) Christelike werklikheidslecr voorhou, en konsekwent die Dooyeweerdiaanse taalspel waarin hy gesosialiseer is, specl, gaan ons paaic uiteen. Behalwe dat ek geen aanklank vind by Dooyeweerd se jargon en sy fragmentering van 'die werklikheid' in netjiese hokkics-en-vakkies walaruit jy soms sekere hokkies kan abstraheer en hulle later wecr enkapties kan vervleg nic, meen ek dat ons duidelik moet raaksien dat ook Dooyeweerd se model 'n konstriksie van 'n kensubjek is, en dus nic sonder meer gelyk aun 'die werklikheid' en 'die Christelike werklikheidsbeskouing' is nie. Watarom kies Ouweneel byvoorbeeld Dooyeweerd en nie H.G. Stoker of J.A.I. Taljalard of D.F.M. Strauss se Christelik-filosofiese kosmologieë nie? En belangriker: waarom verskil hierdie filosoficë van mekaar? Hierdie verskille illustreer tog dat nie een van hierdie kosmologieë 'n presiese en 'korrekte' beskrywing van die werklikheid is nie.

7.6 Ouwencel se slotstelling bevestig sy fideïstiese ${ }^{14}$ epistemologiese aannames:

Die ware werklikhcid kan slegs geval word 'n 'n bo dic logiese denke en alle ceorievermende uilgalande kennis van die gelowige harr, wat danksy dic wedergeboorte en deur die verligling

\footnotetext{
${ }^{13}$ t.c1 op sy formulering en my kursivering: "Hier keun die essensiele begrip wet ler sprake, In dic (hrisclik-wysgerige werklikhcidsbeskouing hel die insig deurgebreck dat ..." ( I9)1:180)

1. Kyk Frankenberry (1987:8 c.v.) vit 'n bespreking van die problene met fideisme as "mode of justilication".
} 
van die Heilige (iees in dic greep van die geopenbaarde waarheid van die Skril gerig is en 'crvul is van Hom wat die Waarheid is' (1991:183) (my kursiverings).

Hoe is rasionele wetenskaplike werk buite die klein kring (Van Huyssteen, 1986:98, praat in hierdie verband tereg van 'n 'ghetto') van mense wat hierdie atanname deel dan nog enigsins moontlik? Hoe is wetenskaplike uitsprake wat op hierdie gronde gemaak word toetsbaar? Is intersubjektiwiteit, verstaanbaarheid en kritiseerbaarheid dan nog enigsins moontlik? Wat maak 'n mens in die geval van mense wat beide aanspraak maak op hierdie bo-logiese deur-dieHeilige-Gees-verligte kennis en wat Romeine 7 uiteenlopend verklaar (soos wat inderdaad gebeur!)? Op watter gronde gaan hulle met mekaar in gesprek tree om nie eers te praat van gronde vir gesprek met jemand wat nié op sulke kennis aanspraak maak nie?

7.7 Speel die graad van 'n wetenskaplike se geloofsoortuigings 'n episremologiese rol? Maak commitment 'n teorie goed of sleg?

7.8 Ouweneel se afwysing van die fundamentalisme, veral binne die konteks warin teologie op Potchefstroom beoefen word (kyk Loader, 1979:14-19) is, 'n belangrike bydrac wat ek positief waardeer (al doen hy dit myns insiens nie konsekwent nie, kyk \$7.4).

7.9 Die keuse vir 'n koherensieteorie van waarheid bo 'n korrespondensieteorie van watarheid kan myns insiens goed gemotiveer word en lewer bevredigende resultate indien dit aangewend word binne die konteks van die interpretasie van geskrewe tekste. Ouweneel stel 'n geldige probleem as hy vra na die breëre implikasies van 'n koherensieteorie van waarheid (veral vir die ontologie). Dit is 'n siak wat verdere navorsing en voortgesette diskussie verg.

\section{8. 'N NAGEDAGTE - WA'T EINTLIK 'N HOOFGEDAGTE IS}

Die PU vir CHO se Christelike karakter en Christelike wetenskapsbeoefening word deur die universiteit baic hoog geag en as kleinood gekoester.

Watter pad galan ons op die Potchefstroomse Universiteit vir Christelike Hoër Onderwys loop? 'n Soort fideïstiese foundationalisme gebaseer op Dooyeweerd? Hoe kan ons dan in sinvolle diskussie wees met die post-moderne intellektuele wêreld 
waarin ons lewe? Sodanige diskussie is tog qua universiteit. Gaan ons ons toevlug neem tot 'n klein esoteriese kringetjie van eendersdenkendes - slegs ons en 'n paar klein 'geesgenootlike' kollegas in Nederland en die VSA? En heel belangrik, eg pragmaties is ons gedwing om ook te vra: gaan die nuwe Suid-Afrika se belastingbetalers vir so'n soort wetenskapsbeoefening betaal?

Ons hóéf natuurlik nie ons horisonne tot die klein kring te beperk nie. Die bekende filosoof Nicholas Wolterstorff (vroeër van die 'geesgenootlike' Calvin College in Grand Rapids) is vandag hoof van die Departement Filosofie van Yale University. Dit sê nogal iets. En hy is steeds 'n Christen, meer nog, 'n reformatoriese Christen. Nog 'n voorbeeld is Alvin Plantinga, 'n reformatoriese Christen wat aangestel is in 'n prestige lecrstuel alan die University of Notre Dame. Beide Wolterstorlf en Plantinga is bekend vir hulle anti-foundationalisme. Itulle bydrae word buite 'eie kring' so hoog geag dat Percescepe (1091:125) skryf dat hulle help "to redirect the philospohy of religion in our dily".

()m op geloofwalardige en verantwoordelike wyse - juis binne die post-moderne geestesklimatat van ons eie tyd - ons wetenskap en soeke na waarheid te beoefen, dit is die uitclaging walarvoor die wetenskapstradisie van die $\mathrm{PU}$ vir $\mathrm{Cl} I \mathrm{O}$ ons stel.

\section{BHIBI.KOGKRAIII:}

BERR(BER, PLTIER L., \& LUCKMANN, T. 1984. The social construction of reality : A trealise in the sociulogy of knowledge. Middlesex : Penguin.

[3E:RNSTEIN, R. I. 1983. Beyond objectivism and relativism: Science, hermeneutics, and praxis. Philiddelphia : University of Pennsylvania Press.

BL.I:JCHI:R, I. IUSO. Contemporary hermenculics: Hermencutics as method, philosophy and critique. london : Roulledge and Kegan Paul.

BOI:SAK. A. A. 1986. What belongs to Cacsar? Once again Romans 13. (In Bocsak, A.A. d VillaVicencio, (: When prayer makes news. Philadelphia, P.A. : Westminster. p.138-157.)

BCI:SAK, A. A., and VIILA-VICENCIO, C. 1986 ceds. When prayer makes news. Philadelphia, PA: Westminsler.

BCRNKANIM, (i. 1977. The Letter to the Romans as Paul's last will and testament. (In Donfricel, K.P. The Romatns debalc. Minncapolis, Mimn. : Augslourg. p. 17-31.)

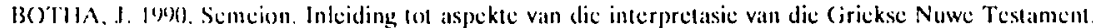
Preloria : N.Ci. Kerklockliandel.

BCTHA, P. W. 1985. Address by president P.W. Botha on the occasion of the award of the freedom of Moria on 7 April 1085. Cape Town : Olfice of the State President.

BRINK, A.P. 19S5. Transgressions : a quantum approach to literary construction. Jemmat of Literany Sinclies, $1(3): 10-27$.

( OMSTOC K, (;. L. 1989. Is postmodern religious dialogue possible? Faith and philesophy, 6(2):189.97.

(CTIERI:I.I, P. \& TURNER, M. 1989). Linguistics and biblical interpretation. London : spck. 
DONIRIED, K. P. 1977a. False presuppositions in the study of Romans. (In Donfried, ed. 1977:120. 148.)

DONFRIED) K.P. 1977b. The nature and scope of the Romans debate. (In Donfried, 1977:ix-xvii).

DONFRIED, K.P. red. 1977. The Romans debatc. Minncanolis, Minn. : Augsburg.

DU PLOOY, H. 1990. Stromings, sosiokodes en representasies. Literator, 11(3):70-94

DUNN, I. D. (i. 1975. Rom 7,14-25 in the theology of Paul. Theologische Zeithing, 31:257-73.

FRANKENIBERRY.N. 1987. Religion and radical empiricism. Albany : State University of New York Prcs.

HASEL, H. 1978. New Testament Theology. Basic issues in the current debate. Grand Rapids, Michigan : Ferdmans.

JER V'ELL, J, 1977. The letter to Jerusalem. (In Donfried, 1977:61-74.)

KARRIS, R. I. 1977. Romans 14:1-15:13 and the occasion of Romans. (In Donfried, 1977:75-99.)

KLEIN, (i. 1977. Paul's purpose in writing the epistle to the Romans (In Donfried, 1977:32-49.)

LAWRENCE, B. 1989. Defenders of Cod. The fundamentalist revolt against the nodern age. San Francisco: Harper \& Row.

LOADER, I. A. 1979. The use of the Bible in conventional South African theology (In Vorster, W.S. red. Scripture and the use of Scripture. Pretoria: UNISA. (Proceedings of the second symposium of the Institute for Theologicisl Rescarch), p. 1-27).

MANSON. T.W. 1977. St' Paul's letler 10 the Romans - and othors. (In Donfried, 1977:1-16.)

MINEAR, P. 1971. The ohedience of faith. The purpose of Paul in the epistle to the Romans. Studies in Biblical Theology 11, 19. London : SC.M.

MOUTON, I \& PAUV, JC. 1988 . Foundationalism and fundamentalism: a crilique. (In Mouton, J. et al., reds. Paradigms and progress in theology. (13SRC Studies in Rescarch Methodology, 5). Prcturia : HSRC. p. 176-186.)

NEWMAN, B. M. 1983. Once again - the question of the ' $\mathrm{l}$ ' in Romans 7 :7-25. The Bible Transtator, $.34: 124-35$

NIDA. E. A., C. R. TABER. 1974. The theory and practice of translation. Leiden : E.J. Brill.

NYGREN, A. 1952. (ommentary on Romans. (Engelse vertaling van Pauli Brev till Romarna). London : $S(1$

OUWENEEl. W.J. 1\%)1. Korrespondensic of koherensic? Diskussie veral na atanleiding vat J. Botha: Semion (1)(1) Kors, 50(2): 185-215.

PERCESEPE, (i. J. 1(X)1. The unbearable lightness of being postmodern. Christian Scholar's Review.

PRIOP, A. N. 1967. Correspondence theory of trutk. Ed. P. Edwards. In The Encyclonedia of Philosophy Vol. 1, 223-32. New York : MacMillan

RIDDERBOS, 11. $1977<1959>$. Aan de Romeinen. Commentatr op hel Nicuwe Testament. Kampen : Kok

SIHPLEY, J. T. IOKG. Dictionary of world literary terms, forms, technique, criticism. Boston : Writcr.

SNIIT, D. J. IWI. Wat betcken 'dic Bybel sê'? 'n Tipologic van lescrskonstrukte. Henormade Teologiese Sinclics, $47(1): 167-85$

SWANEPOEL, J. 198\%, literêre analisc van dic New Testament, Koers, 51(3):298-327.

SWANEPOEI., J. 1989. (jebed in die cumina minora van Catullus : 'n Literêre en metodologiese studic, rocgespits op enkele probleme in verband met literêre interpretasic. Polchefstroom. ('Proelskrif (D.Litt) - PU vir (IIIO).

VAN HUYSSTEEN, WENTZEL. 1986. Tcologic as krilicsc gcloofsverantwoording. Pretoria : R(iN

VAN IIUYSSTEEN, WENTZEL. IO(). Some remarks on 'The explanatory role of religious experience and helicfs in theology and science'. Unpublished Working Paper, Center for Theological Inquiry, Princcion.

VOCFLS, W. 1985. Inspiration in a linguistic mode. Biblical Theology Bulletin, 15(3):87-93. 
VORSTER, J. N. 1988. The use of Scripturc in fundamentalism (In Mouton, J., Van Aardc, A.G. \& Vorster, W.S. reds. Paradigms and progress in theology. HSRC Studics in Research Methodology, red. Mouton, J. Pretoria : HSRC. p. 155-175.)

WEDDERBURN, A. J. M. 1989. The reasons for Romans. Edinburgh : T\&T Clark.

WEIFEL, W. 1977. The Jewish community in ancient Rome and the origins of Roman Christianity. (In Donfricd, 1977:100-19.)

WESTMINSTER THEOLOGICAL SEMINARY CATALOG 1986-1988. Philadelphia : Pennsylvania.

WHITE, A. R. 1967. Coherence theory of truth. Ed. P. Edwards. (In The Encyclopedia of Philosophy Volume 1. New York: MacMillan.)

WOLTERSTORFF, NICHOLAS. $1984<1976>$. Reason within the bounds of religion. (Sccond cdition) Grand Rapids, Mich. : William B. Ecrdmans. 
